\title{
Perbedaan Kadar Laktat Dehidrogenase (LDH) pada Berbagai Derajat Keparahan Preeklampsia
}

\section{Differences in Lactate Dehydrogenase (LDH) Levels at Various Degrees of Preeclampsia Severity}

\author{
Tendi Novara ${ }^{1}$, Ika Murti Harini', Sutrisno ${ }^{3}$ \\ ${ }^{1}$ Departemen Anestesi dan Terapi Intensif Fakultas Kedokteran Universitas Jenderal Soedirman Purwokerto \\ ${ }^{2}$ Departemen Histologi Fakultas Kedokteran Universitas Jenderal Soedirman Purwokerto \\ ${ }^{3}$ Departemen Obstetri dan Ginekologi Fakultas Kedokteran Universitas Jenderal Soedirman Purwokerto
}

\begin{abstract}
ABSTRAK
Preeklampsia adalah penyakit kehamilan akibat disfungsi plasenta serta merupakan penyebab kesakitan dan kematian maternal maupun perinatal di Indonesia. Laktat dehidrogenase (LDH) adalah enzim intraseluler yang dapat menandai adanya jejas pada sel dan jaringan. Penelitian ini bertujuan untuk mengetahui perbedaan kadar LDH pada berbagai derajat keparahan preeklampsia. Penelitian ini menggunakan desain analitik observasional dengan pendekatan kasus kontrol. Subjek dibagi menjadi 3 kelompok yaitu normotensi, preeklampsia ringan (PER) dan preeklampsia berat (PEB). Data dianalisis menggunakan uji Kruskal-Wallis dan Mann Whitney. Hasil penelitian didapatkan perbedaan kadar LDH antara kelompok normotensi dengan PER $(p=0,031)$ dan antara normotensi dengan PEB $(p=0,039)$ dengan kadar LDH pada PEB secara bermakna paling rendah dibandingkan dengan PER dan normotensi.
\end{abstract}

Kata Kunci: Derajat keparahan preeklampsia, laktat dehidrogenase, normotensi, preeklampsia berat (PEB), preeklampsia ringan (PER)

\begin{abstract}
ABSTRAK
Preeclampsia is a disease in pregnancy due to placental dysfunction and causes maternal and perinatal morbidity and mortality in Indonesia. Lactate dehydrogenase ( $L D H)$ is an intracellular enzyme that may indicate the injury to cells and tissues. This study aimed to determine the differences in $L D H$ levels in various degrees of preeclampsia severity. The design of this study was an analytic observational case-control approach. Subjects were divided into three groups, i.e. normotensive, mild preeclampsia, and severe preeclampsia. Data were analyzed using Kruskal-Wallis and Mann Whitney. The results showed differences in the levels of $L D H$ between normotensive group with mild preeclampsia $(p=0.031)$ and between normotensive with severe preeclampsia ( $p=0.039)$. This study showed that $L D H$ levels in severe preeclampsia were significantly the lowest compared to mild preeclampsia and normotensive.
\end{abstract}

Keywords: Lactate dehydrogenase, mild preeclampsia, normotensive, severity of preeclampsia, severe preeclampsia

Korespondensi: Tendi Novara. Departemen Anestesi dan Terapi Intensif Fakultas Kedokteran Universitas Jenderal Soedirman Purwokerto, Jl. Dr. Gumbreg No. 1 Mersi Purwokerto Timur 53112 Tel. (0281) 622022/081326530548 Email: tendi.novara@unsoed.ac.id

DOI: http://dx.doi.org/10.21776/ub.jkb.2019.030.04.7 


\section{PENDAHULUAN}

Preeklampsia merupakan penyakit dalam kehamilan yang ditandai dengan disfungsi plasenta, aktivasi endotel dan koagulasi yang menyebabkan respon sistemik maternal. Secara klinis preeklamsia ditegakkan berdasarkan tanda adanya hipertensi (tekanan darah sistol $\geq 140 \mathrm{mmHg}$ atau tekanan darah diastol $\geq 90 \mathrm{mmHg}$ ), disertai proteinuria ( $\geq 300 \mathrm{mg} / \mathrm{dl}$ dalam urin tampung 24 jam) pada usia kehamilan lebih dari 20 minggu atau segera setelah persalinan (1). Preeklampsia merupakan salah satu penyebab tingginya angka kesakitan dan kematian maternal dan perinatal, baik di dunia maupun di Indonesia. Meskipun penyebab kematian utama maternal dan perinatal adalah karena perdarahan, namun proporsi tersebut mulai turun, sedangkan kasus kematian karena preeklampsia justru semakin meningkat (2). WHO memperkirakan kasus preeklampsia di negara berkembang tujuh kali lebih tinggi daripada di negara maju. Prevalensi preeklampsia di negara maju sebesar 1,3\%-6\%, sedangkan di negara berkembang sebesar 1,8\%18\%. Di Indonesia, insiden preeklampsia adalah sebesar $128.273 /$ tahun atau sekitar $5,3 \%$ (1).

Mekanisme preeklampsia dikaitkan dengan kelainan pada plasenta yaitu terjadinya infark dan sklerosis arteriol plasenta. Terdapat dua model teori yang dikembangkan pada patogenesis preeklampsia, yaitu remodeling arteri spiralis yang tidak lengkap sehingga berkontribusi terhadap iskemik plasenta, serta pelepasan antiangiogenik dari plasenta yang iskemik tersebut ke dalam sirkulasi maternal yang pada akhirnya menyebabkan kerusakan endotel (3). Laktat dehidrogenase (LDH) adalah enzim intraseluler yang terdapat di hampir semua sel hidup. LDH dibutuhkan untuk mempertahankan glikolisis dan produksi adenosina trifosfat (ATP) pada kondisi minim oksigen dengan cara meregenerasi nikotinamida adenina dinukleotida bentuk teroksidasi $\left(\mathrm{NAD}^{+}\right)$dari nikotinamida adenina dinukleotida bentuk tereduksi (NADH). LDH berfungsi mengkatalisis proses reduksi piruvat menjadi laktat dan menghasilkan $\mathrm{NAD}^{+}$. Produknya, yaitu laktat merupakan hasil samping dari reaksi ini. LDH mempengaruhi proses pembentukan asam laktat, dan kadar LDH serta asam laktat umumnya meningkat jika ada kerusakan sel (4). Penelitian yang dilakukan oleh Mari et al., menyatakan bahwa semakin parah derajat preeklampsia, semakin tinggi kadar LDH. Terdapat perbedaan bermakna derajat keparahan preeklampsia pada pasien yang memiliki kadar LDH >800 IU/l dibandingkan dengan pasien yang memiliki kadar LDH <800IU/I. Dinyatakan bahwa laktat dehidrogenase berpotensi sebagai marker biokimia untuk menilai derajat keparahan preeklampsia-eklampsia (5). Penelitian lain juga menyebutkan bahwa semakin parah derajat preeklampsia, semakin tinggi kadar LDH-nya.

Penelitian kadar LDH pada pasien preeklampsia di Purwokerto Banyumas Jawa Tengah, khususnya di Rumah Sakit Umum Daerah (RSUD) Prof. Dr. Margono Soekarjo Purwokerto belum pernah dilakukan sebelumnya. RSUD Prof. Dr. Margono Soekarjo Purwokerto merupakan rumah sakit rujukan di Provinsi Jawa Tengah yang banyak menerima pasien di wilayah Jawa Tengah bagian selatan dan barat, dengan karakteristik pasien preeklampsi memiliki tingkat keparahan dan komplikasi ringan hingga berat. Oleh karena itu perlu dilakukan penelitian ini dengan tujuan untuk mengetahui karakterisasi perbedaan tingkat kerusakan sel secara sistemik melalui indikator LDH pada berbagai derajat keparahan preeklampsia di RSUD Prof. Dr. Margono Soekarjo Purwokerto.

\section{METODE}

Penelitian ini menggunakan desain observasional analitik dengan pendekatan kasus kontrol untuk mengetahui perbedaan kadar LDH pada berbagai derajat keparahan preeklampsia di RSUD Prof. Dr. Margono Soekarjo Purwokerto. Persetujuan etik diperoleh dari Komisi Etik Penelitian Fakultas Kedokteran Universitas Jenderal Soedirman Purwokerto.

Pengambilan sampel menggunakan metode nonprobability sampling, dan pemilihan sampel menggunakan consecutive sampling. Dari pasien yang datang berurutan dipilih yang memenuhi kriteria hingga jumlah sampel terpenuhi. Sampel dikelompokkan dalam 3 kelompok, yaitu kelompok normotensi, preeklampsia ringan (PER), preeklampsia berat (PEB), dan masing-masing kelompok diukur kadar LDH darahnya. Berdasarkan perhitungan

Tabel 1. Kriteria preeklamsia dalam urin tampung 24 jam atau dengan pemeriksaan kualitatif $\geq 1+$ pada sampel urin acak

\begin{tabular}{|c|c|c|c|}
\hline & Tekanan Darah Sistolik & Tekanan Diastolik & Terdapat Proteinuria \\
\hline Preeklampsia Ringan (PER) & $\geq 140 \mathrm{mmHg}$ & $\geq 90 \mathrm{mmHg}$ & $300 \mathrm{mg} / \mathrm{dl}$ \\
\hline $\begin{array}{l}\text { Preeklampsia Berat (PEB) disertai salah satu } \\
\text { kriteria berikut ini : } \\
\text { a). Trombosit }<100.000 / \mathrm{mm} 3 \text {; } \\
\text { b). Peningkatan kadar enzim hepar } \geq 2 x \text { dari } \\
\text { normal; } \\
\text { c). Kreatinin serum }>1,1 \mathrm{mg} / \mathrm{dl} \text { (insufisiensi } \\
\text { ginjal) atau pengeluaran urin }<500 \mathrm{ml} \text { dalam } \\
24 \text { jam (oligouria); }\end{array}$ & & & \\
\hline $\begin{array}{l}\text { d). Edema paru atau sianosis; } \\
\text { e). Gangguan serebral atau gangguan } \\
\text { penglihatan dengan onset baru; } \\
\text { f). Nyeri berat persisten pada kuadran kanan } \\
\text { abdomen atau regio epigastrik. } \\
\text { Kriteria normotensi adalah kehamilan } \geq 20 \\
\text { minggu tanpa preeklampsia atau eklampsia } \\
\text { dengan tekanan sistolik } 100-140 \mathrm{mmHg} \text { dan } \\
\text { tekanan diastolik } 60-90 \mathrm{mmHg} \text { tanpa } \\
\text { proteinuria. }\end{array}$ & $\geq 160 \mathrm{mmHg}$ & $\geq 110 \mathrm{mmHg}$ & $300 \mathrm{mg} / \mathrm{dl}$ \\
\hline
\end{tabular}


sampel untuk studi kasus kontrol, besar sampel setiap kelompok adalah sebesar 13 (6). Untuk mengantisipasi adanya drop out, maka jumlah sampel ditambah sebesar $10 \%$ menjadi 14 orang untuk masing-masing kelompok.

Pemeriksaan LDH menggunakan sampel darah responden yang diambil di vena ante kubiti sebanyak 3cc. Darah kemudian disentrifugasi, diambil serumnya dan diukur kadar LDHnya menggunakan metode Elisa (Bioassay Technology Laboratory).

Data dianalisis secara univariat dan bivariat. Usia responden dianalisis menggunakan uji ANOVA, status paritas menggunakan uji Kolmogorov-Smirnov, sedangkan usia kehamilan dan kadar LDH menggunakan uji Kruskal-Wallis. Kadar LDH diuji lebih lanjut menggunakan Mann Whitney untuk mengetahui perbedaan antar kelompok. Hasil analisis dianggap bermakna bila $\mathrm{p}<0,05$.

\section{HASIL}

Hasil penelitian menunjukkan tidak ada perbedaan bermakna rerata usia ibu pada ketiga kelompok normotensi, PER dan PEB $(p=0,104)$. Kelompok normotensi memiliki rerata usia terendah $(28,64 \pm 5,44)$, sedangkan kelompok PEB memiliki rerata usia tertinggi $(33,93 \pm 8,11)$. Pada kelompok PEB, terdapat 1 orang berusia 19 tahun dan 1 orang berusia 47 tahun. Hasil analisis statistik juga menunjukkan bahwa tidak ada perbedaan bermakna usia kehamilan antara kelompok normotensi, PER dan PEB $(p=0,408)$. Pada kelompok PEB, rerata usia kehamilan adalah $35,86 \pm 3,94$ minggu, sedangkan pada kelompok normotensi, rerata usia kehamilannya $37,50 \pm 2,77$ minggu. Pada penelitian ini, status paritas juga tidak ada perbedaan bermakna antara ketiga kelompok tersebut $(p=0,916)$ (Tabel 2).

Tabel 2. Karakteristik responden penelitian

\begin{tabular}{|c|c|c|c|c|}
\hline Variabel & $\begin{array}{l}\text { Normotensi } \\
\quad(n=14)\end{array}$ & $\operatorname{PER}(n=14)$ & PEB (n=14) & p \\
\hline Usia ibu (tahun) & $28,64 \pm 5,44$ & $31,43 \pm 5,19$ & $33,93 \pm 8,11$ & $0,104^{a}$ \\
\hline Min-maks & $21-38$ & $20-38$ & $19-47$ & \\
\hline $\begin{array}{l}\text { Usia kehamilan } \\
\text { (minggu) }\end{array}$ & $37,50 \pm 2,77$ & $36,36 \pm 4,52$ & $35,86 \pm 3,94$ & $0,408^{b}$ \\
\hline Status paritas & & & & $0,916^{\circ}$ \\
\hline 1 & 6 & 2 & 5 & \\
\hline $2 />$ & 8 & 12 & 9 & \\
\hline
\end{tabular}

\section{Keterangan:}

a : nilai $p$ tidak ada perbedaan signifikan dengan uji ANOVA

$\mathrm{b}$ : nilai $\mathrm{p}$ tidak ada perbedaan signifikan dengan uji Kruskal-Wallis

c : nilai $p$ tidak ada perbedaan signifikan dengan uji KolmogorovSmirnov

Uji Kruskal-Wallis (Tabel 3) menemukan adanya perbedaan rerata kadar LDH antar kelompok dengan kadar tertinggi adalah kelompok normotensi $(183,53 \pm 20,78)$, diikuti kelompok PER $(172,58 \pm 13,61)$ dan terendah adalah kelompok PEB $(167,63 \pm 26,40)$. Uji Mann Whitney menunjukkan bahwa kadar LDH pada kelompok normotensi secara bermakna memang lebih tinggi bila dbandingkan dengan kelompok PER $(p=0,031)$ dan PEB $(0,039)$. Meskipun kadar LDH pada kelompok PER lebih tinggi bila dibandingkan PEB namun perbedaan tersebut tidak bermakna secara statistik $(0,783)$.
Tabel 3. Rerata Kadar LDH pada Berbagai Derajat Keparahan Preeklampsia

\begin{tabular}{lccc}
\hline Derajat Keparahan & Rerata \pm SD & $\begin{array}{c}\text { P (Kruskal- } \\
\text { Wallis) }\end{array}$ & $\begin{array}{c}\text { Mann } \\
\text { Whitney }\end{array}$ \\
\hline Normotensi & $183,53 \pm 20,78$ & & $\mathrm{a}$ \\
PER & $172,58 \pm 13,61$ & $0,049^{*}$ & $\mathrm{~b}$ \\
PEB & $167,63 \pm 26,40$ & & $\mathrm{~b}$ \\
\hline
\end{tabular}

Keterangan:

* : nilai $\mathrm{p}<0,05$ berbeda bermakna dengan uji Kruskal-Wallis

a : nilai $p$ tidak ada perbedaan signifikan dengan uji ANOVA

$\mathrm{b}$ : nilai $\mathrm{p}$ tidak ada perbedaan signifikan dengan uji Kruskal-Wallis

c : nilai $\mathrm{p}$ tidak ada perbedaan signifikan dengan uji Kolmogorov-

Smirnov

\section{DISKUSI}

Hasil penelitian menunjukkan bahwa tidak terdapat perbedaan bermakna usia ibu antar kelompok normotensi, PER dan PEB, meskipun usia pada pada kelompok normotensi paling rendah dan tertinggi pada kelompok PEB. Studi yang dilakukan Bilano et al., menyatakan bahwa usia lebih dari 30 tahun lebih berisiko terjadi preeklampsia/eklampsia dibandingkan dengan usia dibawah 30 tahun (7). Penelitian Luealon \& Phupong menyebutkan bahwa usia >35 tahun lebih berisiko terjadi preeklampsia. Hal ini berkaitan dengan kerusakan progesif endotel vaskular karena proses penuaan maternal dan obstruksi arteriol spiralis maternal akibat atherosis, yang kemudian dapat menginduksi preeklampsia (8). Pada PEB, ditemukan satu orang ibu dengan usia kurang dari 20 tahun (19 tahun). Studi sebelumnya menyebutkan bahwa usia ibu merupakan faktor risiko yang masih kontroversial dan belum bisa dipastikan hingga sekarang (9). Preeklampsia dianggap sebagai penyakit pada kehamilan pertama. Risiko preeklampsia meningkat pada wanita yang terpapar sperma terbatas dibandingkan dengan wanita yang telah lama terpapar sperma dengan pasangan yang sama. Disebutkan bahwa terdapat efek protektif dari paparan sperma jangka panjang dengan pasangan yang sama. Hal ini menjelaskan bahwa usia muda kurang dari 20 tahun juga berisiko mengalami preeklampsia dibandingkan dengan wanita yang berusia lebih dari 20 tahun (10).

Meskipun secara statistik tidak bermakna, terdapat kecenderungan perbedaan usia kehamilan menurut derajat preeklampsia. Rerata usia kehamilan ibu dengan PEB (35,86 minggu) lebih pendek dibandingkan dengan PER (36,86 minggu) dan usia kehamilan ibu dengan PER lebih pendek dibandingkan ibu dengan normotensi $(37,50$ minggu). Pada penelitian ini, ibu dengan PER dan PEB memiliki usia kehamilan kurang dari 37 minggu dan usia kehamilan kurang dari 37 minggu merujuk pada kondisi kelahiran preterm (11). Penelitian sebelumnya membandingkan luaran kelahiran pada preeklampsia juga menunjukkan bahwa ibu dengan sindroma HELLP memiliki usia kehamilan lebih pendek dibandingkan dengan preeklampsia berat (12). Penelitian lain juga membuktikan bahwa ibu dengan preeklampsia berisiko 4 kali lipat melahirkan preterm dibandingkan dengan ibu yang tidak preeklampsia (13). Studi oleh Murti et al., juga menyatakan bahwa usia kehamilan semakin pendek seiring dengan semakin parahnya preeklampsia (14). Disebutkan bahwa preeklampsia merupakan salah satu etiologi kelahiran preterm (11). Pada preeklampsia, terjadi insufisiensi plasental yang menyebabkan abnormalitas transport nutrisi uretroplasental, kerusakan plasenta dan hal 
tersebut berkaitan dengan komplikasi kehamilan, salah satunya yaitu persalinan preterm (15).

Pada penelitian ini, tidak terdapat perbedaan status paritas antar kelompok normotensi, PER dan PEB. Hasil ini sesuai dengan penelitian sebelumnya yang menyatakan bahwa paritas tidak berkaitan dengan preeklampsia (16). Menariknya pada penelitian ini, perbandingan jumlah ibu antara kelompok normotensi, PER dan PEB berdasarkan status paritas memiliki kecenderungan hasil yang berbeda dengan penelitian sebelumnya. Penelitian ini menunjukkan bahwa kejadiaan PER dan PEB lebih banyak terjadi pada ibu yang melahirkan sebanyak dua kali atau lebih (multipara) dibandingkan dengan ibu yang baru melahirkan satu kali (nullipara). Sedangkan penelitian lain menyebutkan bahwa rerata paritas kelompok normotensi lebih tinggi dibandingkan dengan kelompok preeklampsia (17). Penelitian ini tidak meneliti riwayat preeklampsia pada kehamilan sebelumnya pada ibu yang berstatus multipara. Banyaknya ibu multipara yang mengalami preeklampsia ringan dan berat mungkin disebabkan karena adanya riwayat preeklampsia sebelumnya. Penelitian yang dilakukan oleh Hernández-Díaz et al., menyatakan bahwa terjadi peningkatan risiko preeklampsia jika seorang ibu pernah menderita preeklampsia pada kehamilan sebelumnya (18).

Penelitian ini mengidentifikasi perbedaan bermakna kadar LDH pada derajat keparahan preeklampsia. Kelompok normotensi memiliki kadar LDH paling tinggi, diikuti kelompok PER dan yang paling rendah adalah kelompok PEB. Hasil penelitian ini berbeda dengan penelitian sebelumnya yang menyebutkan bahwa kadar LDH pada PEB lebih tinggi dibanding PER dan kadar LDH pada PER lebih tinggi dibandingkan normotensi (19-21). LDH adalah enzim intraseluler yang ditemukan di hampir semua sel hidup. Pada manusia, LDH ditemukan di sel darah merah, jantung, otot rangka dan otak. LDH berfungsi mengkatalisis proses reduksi piruvat menjadi laktat (22). Sel menghasilkan ATP dari glikolisis. Glikolisis merupakan proses pembentukan piruvat dari oksidasi dan pemecahan glukosa. Piruvat yang dihasilkan dari proses glikolisis kemudian akan ditransfer ke mitokondria untuk memulai siklus Kreb. Jalur ini berjalan jika sel memiliki kapasitas oksidatif yang cukup. Jika kapasitas oksidatif sel tidak mencukupi, maka NADH yang dihasilkan dari glikolisis akan mengalami reoksidasi melalui perubahan piruvat menjadi laktat yang dikatalisis oleh LDH (22). LDH adalah enzim yang secara normal ada di dalam tubuh manusia dalam jumlah minimal. Sel dan jaringan yang

\section{DAFTAR PUSTAKA}

1. Perkumpulan Obstetri dan Ginekologi Indonesia (POGI). Pedoman Nasional Pelayanan Kedokteran: Diagnosis dan Tatalaksana Preeklamsia. Jakarta: POGI; 2016; hal. 1-6.

2. Kementerian Kesehatan Republik Indonesia. Profil Kesehatan Indonesia Tahun 2014. Jakarta: Kementerian Kesehatan RI; 2015: hal. 100.

3. Phipps E, Prasanna D, Brima W, and Jim B. Preeclampsia: Update in Pathogenesis, Definitions, and Guidelines. Clinical Journal of the American Society of Nephrology. 2016; 11(6): 1102-1113.

4. Valvona CJ, Fillmore HL, Nunn PB, and Pilkington GJ. mengalami jejas/kerusakan akan melepaskan LDH ke ekstraseluler (23).

Menariknya, hasil penelitian ini berbeda dengan penelitian sebelumnya yang menyatakan bahwa kadar LDH berpotensi sebagai marker keparahan preeklampsia $(19,21)$. Hasil ini mungkin karena kapasitas oksidatif sel tidak mengalami penurunan, kadar oksigen cukup, sehingga terjadi penurunan kadar LDH pada pasien PEB dan PER dibandingkan normotensi. Asumsi lain yaitu proses keparahan preeklampsi baik PER maupun PEB sudah melewati ambang batas maksimal. Penelitian yang dilakukan oleh Purnomo mengenai kadar asam laktat setelah latihan, menyatakan bahwa waktu berpengaruh terhadap kadar asam laktat. Kadar asam laktat menurun bermakna pada 60 menit setelah latihan dibandingkan dengan kadar asam laktat setelah 5 menit latihan. Hal ini diasumsikan sebanding dengan kadar LDH, yaitu kadar LDH sudah melewati ambang maksimal, sehingga hasil yang didapatkan pada penelitian ini tidak sejalan dengan penelitian sebelumnya (24). Perlu batasan waktu yang akurat dalam pemeriksaan kadar LDH sehingga penggunaannya sebagai marka derajat keparahan benarbenar tepat. Pada penelitian ini, pemeriksaan kadar LDH dilakukan setelah penanganan kegawatdaruratan pada pasien. Berkaitan dengan LDH sebagai marka preeklampsia disarankan pengambilan dan pemeriksaannya dilakukan segera setelah kedatangan pasien di tempat pelayanan kesehatan. Keterbatasan penelitian ini adalah tidak meneliti kadar asam laktat maupun piruvat yang juga berpengaruh pada kadar LDH. Perlu dilakukan studi dengan mengukur pula kadar asam laktat dan piruvat selain LDH. Selain itu, penelitian ini juga tidak meneliti faktor lain yang berperan dalam preeklampsia seperti riwayat preeklampsia sebelumnya, obesitas dan riwayat penyakit ibu.

Hasil penelitian ini menunjukkan bahwa kadar LDH pada PEB secara bermakna paling rendah dibandingkan dengan PER dan normotensi. Hal ini berbeda dengan penelitian sebelumnya yang menyatakan bahwa terjadi peningkatan kadar LDH pada PEB dibandingkan PER dan normotensi. Studi lebih lanjut perlu untuk meneliti kadar asam laktat maupun piruvat yang juga berperan pada kadar LDH.

\section{UCAPAN TERIMAKASIH}

Terima kasih disampaikan kepada Lembaga Penelitian dan Pengabdian Masyarakat Universitas Jenderal Soedirman (LPPM Unsoed) yang telah mendanai penelitian ini.

The Regulation and Function of Lactate Dehydrogenase A: Therapeutic Potential in Brain Tumor. Brain Pathology. 2016; 26(1): 3-17.

5. Mary VP, Chellatamizh M, and Padmanaban S. Role of Serum LDH in Preeclampsia as a Prognostic Factor - a Cross Sectional Case Control Study in Tertiary Care Hospital. International Journal of Reproduction, Contraception, Obstetrics and Gynecology. 2017; 6(2): 595-598.

6. Dahlan MS. Besar Sampel dalam Penelitian Kedokteran dan Kesehatan. Edisi 4. Jakarta: Epidemiologi Indonesia; 2016; hal. 187.

7. Bilano VL, Ota E, Ganchimeg T, Mori R, and Souza JP. 
Risk Factors of Pre-Eclampsia/Eclampsia and Its Adverse Outcomes in Low- and Middle-Income Countries: A WHO Secondary Analysis. Plos ONE. 2014; 9(3): 1-9.

8. Luealon $\mathrm{P}$ and Phupong V. Risk Factors of Preeclampsia in Thai Women. Journal of the Medical Association of Thailand. 2010; 93(6): 661-666.

9. Trogstad L, Magnus P, and Stoltenberg C. PreEclampsia: Risk Factors and Causal Models. Best Practice \& Research. Clinical Obstetrics and Gynaecology. 2011; 25(3): 329-342.

10. Sibai B, Dekker G, and Kupferminc M. Pre-eclampsia. Lancet. 2005; 365(9461): 785-799.

11. Frey $\mathrm{HA}$ and Klebanoff MA. The Epidemiology, Etiology, and Costs of Preterm Birth. Seminars in Fetal and Neonatal Medicine. 2016; 21(2): 68-73.

12. Yildrim G, Güngördük K, Aslan H, Gül A, Bayraktar M, and Ceylan Y. Comparison of Perinatal and Maternal Outcomes of Severe Preeclampsia, Eclampsia and HELPP Syndrome. Journal of the Turkish-German Gynecological Association. 2011; 12(2): 90-96.

13. Davies EL, Bell JS, and Bhattacharya S. Preeclampsia and Preterm Delivery: A Population-Based CaseControl Study. Hypertension in Pregnancy. 2016; 35(4): 510-519.

14. Harini IM, Novara T, dan Sutrisno. Perbedaan Kadar Kalsium Darah pada Kehamilan Preeklampsia dengan Kehamilan Normotensi. Jurnal Kedokteran Brawijaya. 2018; 30(2): 109-113.

15. Morgan TK. Role of the Placenta in Preterm Birth: A Review. American Journal of Perinatology. 2016; 33(3): 258-266.

16. Ganesh KS, Unnikrishnan B, Nagaraj K, and Jayaram S. Determinants of Pre-eclampsia: A Case-control Study in a District Hospital in South India. Indian Journal of Community Medicine. 2010; 35(4): 502-505.

17. Saadat M, Nejad SM, Habibi G, and Sheikhvatan M. Maternal and Neonatal Outcomes in Women with Preeclampsia. Taiwanese Journal of Obstetrics \& Gynecology. 2007; 46(3): 255-259.

18. Hernández-Díaz S, Toh $\mathrm{S}$, and Cnattingius S. Risk of Pre-Eclampsia in First and Subsequent Pregnancies: Prospective Cohort Study. British Medical Journal. 2009; 338: 1-5.

19. Jaiswar SP, Gupta A, Sachan R, Natu SN, and Shaili M. Lactic Dehydrogenase: A Biochemical Marker for Preeclampsia-Eclampsia. Journal of Obstetrics and Gynecology of India. 2011; 61(6): 645-648.

20. Umasatyasri Y, Vani I, and Shamita P. Role of $L D H$ (Lactate Dehydrogenase) in Preeclampsia-Eclampsia as a Prognostic Marker: An Observational Study. International Archives of Integrated Medicine. 2015; 2(9): 88-93.

21. Dave A, Maru L, and Jain A. LDH (Lactate Dehydrogenase): A Biochemical Marker for the Prediction of Adverse Outcomes in Pre-eclampsia and Eclampsia. The Journal of Obstetrics and Gynecology of India. 2016; 66(1): 23-29.

22. Adeva-Andany $M$, López-Ojén $M$, Funcasta-Calderón $\mathrm{R}$, et al. Comprehensive Review on Lactate Metabolism in Human Health. Mitochondrion. 2014; 17: 76-100.

23. Markert CL. Lactate Dehydrogenase. Biochemistry and Function of Lactate Dehydrogenase. Cell Biochemistry \& Function. 1984; 2(3): 131-134.

24. Purnomo M. Asam Laktat dan Aktivitas SOD Eritrosit pada Fase Pemulihan Setelah Latihan Submaksimal. Jurnal Media Ilmu Keolahragaan Indonesia. 2011; 1(2): 155-170. 